Comunicação e Sociedade, vol. 7, 2005, pp. 153-180.

\title{
O custo das não-decisões na imprensa local e regional em Portugal
}

Paulo Ferreira*

\section{Resumo}

O estudo da imprensa local e regional em Portugal está ainda numa fase embrionária. Contudo, pelo que se conhece de alguns estudos, pode afirmar-se que as actuais características do sector são inversamente proporcionais à importância que este tipo de publicações pode e deve assumir nas comunidades locais e regionais. Percebe-se a consequência deste hiato: sem bons jornais, as comunidades locais e regionais ficam tendencialmente amputadas de boa "informação de proximidade". Independentemente de outros factores que podem contribuir para o entendimento desta situação, este artigo irá centrar a sua atenção na dimensão política do problema. A nossa hipótese de trabalho é que a imprensa local e regional portuguesa tem sido vítima das más decisões, e sobretudo das não decisões, que sobre ela os vários Governos têm tomado. A discussão parece-nos especialmente relevante num momento em que o actual Governo (XVI Constitucional) se prepara para pôr em marcha o que garante ser uma verdadeira reforma para o sector.

Palavras-chave: imprensa local e regional, decisão, não-decisão, globalização, espaço público

\section{Introdução}

Quando, em 1995, Jacques Chirac escolheu a imprensa regional para publicar uma carta onde apresentava as razões da sua candidatura à liderança do Estado francês, não o fez por mera simpatia pelos órgãos de comunicação social regional. Fê-lo porque sabia que a imprensa regional francesa é lida pelo dobro dos leitores relativamente àqueles que escolhem a imprensa nacional (vinte milhões contra dez milhões) ${ }^{1}$.

\footnotetext{
* Jornalista do Jornal de Notícias. Prepara dissertação no âmbito do mestrado em Ciências da Comunicação - Ramo de Especialização em Informação e Jornalismo na Universidade do Minho (pferreira@jn.pt)

${ }^{1}$ De acordo com a edição de 1999 do World Press Trends, a circulação média dos diários regionais franceses era, em 1997 de 6193000 exemplares, contra 2313000 dos diários ditos generalistas. Os jornais regionais não diários tinham, nessa altura, uma circulação a rondar os 2336000 exemplares.
} 
Nunca em Portugal se assistiu a um facto semelhante. O anúncio de candidaturas - sejam elas à presidência da República, à liderança do Governo, à liderança de partidos ou mesmo de importantes organismos públicos e privados - é invariavelmente forjado na imprensa nacional. O que faz todo o sentido, na medida em que, ao contrário do que acontece em França e em muitos outros países europeus, a imprensa local e regional portuguesa vive genericamente mergulhada, há demasiados anos, numa profunda letargia.

Os dados que se conhecem sobre a realidade do sector parecem atestá-lo à saciedade, como adiante se verá. Mas se dúvidas sobrassem sobre esta abulia que, no limite, contagia e distorce o chamado espaço público (um espaço democrático de expressão da cidadania, de interacção e de intercomunicação social, seguindo aqui o sentido em que Habermas o concebia), bastaria olhar para a apresentação cronológica dos factos mais relevantes ocorridos no campo da comunicação e dos media portugueses no período que vai de 1995 a 1999. Nesse "contributo para a memória e leitura da segunda metade dos anos 90, no que aos media e à comunicação diz respeito" (Pinto et al. : 2000:11), são elencadas 1325 referências a notícias sobre este campo vindas a lume nos principais órgãos da imprensa nacional. Quantas falam sobre a realidade dos media regionais? Sessenta e seis (66). Contas feitas, menos de 5\% do total $(4,98 \%$, para sermos exactos) $)^{2}$.

A percentagem espanta? Sim e não.

Espanta, se tivermos em consideração que existem em Portugal, só no que diz respeito à imprensa escrita local e regional, cerca de 900 títulos devidamente registados no Instituto de Comunicação Social ${ }^{3}$. Com tanto jornal, os acontecimentos dignos de nota foram tão exíguos? As decisões tomadas pelos proprietários dos títulos e pelo Estado relativamente à marcha do sector foram assim tão escassas?

Não espanta se, como faremos adiante, olharmos para as principais características da imprensa local e regional e para o conteúdo das decisões que sobre ela foram tomadas desde 1975.

E volta a espantar se analisarmos o que dizem três estudos de opinião sobre a imprensa local e regional portuguesa. O primeiro, realizado em 2000 pelo Instituto de Pesquisa e Opinião de Mercado (IPOM) ${ }^{4}$, mostra que 1600 dos 2859 entrevistados

\footnotetext{
${ }^{2}$ Os factos, eventos e acontecimentos referenciados na cronologia "são, em grande medida e acima de tudo, indícios e sintomas. Remetem para um lado invisível ou mais difícil de descortinar, mas nem por isso menos rico e dinâmico, que convém não perder de vista" (Pinto et al., 2000: 136). O trabalho é de enorme relevância, não só porque, para o período em análise, nada de análogo existe em Portugal, mas também porque permite perceber as grandes linhas de força e as decisões tomadas neste campo, na medida em que a compilação foi feita nos jornais Expresso, Diário de Notícias e Público, publicações que, pelo seu carácter, tendem a dar mais visibilidade às grandes decisões políticas.

${ }^{3}$ Possuindo embora metade da superfície do nosso país, os Países-Baixos têm 68 jornais regionais. A Finlândia conta com 215 títulos, a Noruega tem 180 e a Suécia tem 170. Acresce que existe uma enorme disparidade entre o nosso país e os aqui usados para a comparação no que diz respeito aos índices de leitura.

4 "A imprensa regional em Portugal - elementos para a gestão estratégica e planeamento publicitário". O trabalho foi feito a pedido da Associação de Imprensa Não Diária (AIND) - agora apenas Associação Portuguesa de Imprensa - e subsidiado pela Secretaria de Estado da Comunicação Social. O IPOM estava à altura devidamente credenciado junto da Alta Autoridade para a Comunicação Social.
} 
liam, na altura do trabalho, mais jornais regionais que nacionais. Isto é: cerca de $56 \%$ da amostra então escolhida optava por ler notícias de âmbito regional em detrimento das de âmbito nacional, o que evidencia bem uma das principais características deste tipo de imprensa: "a estreita solidariedade com a estrutura social local" (Alves, 1990: 242).

Em Outubro de 2003 ficaram a conhecer-se as conclusões de um outro estudo sobre a imprensa regional, este da Marktest ${ }^{5}$. Mais de metade $(50,9 \%)$ dos inquiridos referiu ler ou folhear jornais regionais, sendo que os semanários são os títulos mais procurados $(23,1 \%$ dos leitores prefere semanários nacionais, mas 31,6\% opta por ler os semanários regionais). Ainda assim, o número de pessoas que têm algum tipo de contacto com os jornais nacionais ditos de informação geral $(64,7 \%)$ é superior aos leitores que contactam com a imprensa regional (50,9\%).

Mais recentemente, um novo estudo da Marktest veio confirmar estes valores. Divulgado no Dia Nacional da Imprensa (24 de Setembro de 2004), promovido pela Associação Portuguesa de Imprensa, o Bareme/Imprensa Regional volta a mostrar que 51\% dos portugueses afirma ler jornais regionais. Cerca de $40 \%$ do universo analisado (mais de 8300 indivíduos) lê, simultaneamente, jornais nacionais e títulos de cariz regional. Para alguns distritos, os hábitos de leitura de imprensa regional encontrados estão mesmo acima da média. São os casos de Coimbra (75,8\%) e Castelo Branco (75\%). Porto e Lisboa estão entre os distritos de menor consumo deste tipo de publicações. ${ }^{6}$

Alguma coisa parece não bater certo. Se os estudos científicos mostram de forma evidente a importância da imprensa local e regional, por que razão não tem ela visibilidade na leitura cronológica a que aludimos? A resposta talvez esteja no facto de os estudos apenas mostrarem as potencialidades da imprensa local e regional. Não falam das suas dificuldades e, por isso mesmo, não podem retratar a fraca qualidade da esmagadora maioria dos títulos. Acima de tudo, não explicam - nem era esse o objectivo - o atraso estrutural em que o sector se encontra. Podem ser estas, entre outras, as razões que explicam a quase ausência de referências aos media regionais na cronologia.

O objectivo deste ensaio passa, justamente, pelo debate que nos pode conduzir às causas e consequências do hiato entre a quantidade e a qualidade na imprensa local e regional portuguesa. O que atrás fica escrito permite-nos assumir que a esmagadora maioria dos títulos está longe de fazer o que se lhe pede: ser "um canal de transmissão de mensagens capaz de desempenhar um papel activo na 'fabricação de ideias' dentro de uma comunidade em cujo seio cresceu a nossa cultura pessoal" (Mathien, 1983:32). Desde logo, porque, em boa medida, a sua sobrevivência tem sido assegurada muito à custa dos apoios que o Estado tem disponibilizado. Citemos apenas dois exemplos: dos 900 títulos, 645 beneficiam de apoios estatais; e, só entre 1999 e 2003, foram gastos mais de 89 milhões de euros em ajudas (ver Quadros III a VII).

\footnotetext{
5 "Bareme Imprensa Regional", promovido pela Marktest e pela AIND. A amostra tem por base mais de quinze mil entrevistas. Só foram tidos em consideração jornais com periodicidade máxima quinzenal e com mais de cinco referências espontâneas durante o estudo-piloto. Por outro lado, não foram contemplados os jornais de distribuição gratuita.

6 "Maioria diz ler imprensa regional", in Público de 25 de Setembro de 2004. E "Imprensa: mais de metade dos portugueses afirma ler jornais regionais”. Despacho da Agência Lusa de 24 de Setembro de 2004.
} 
Independentemente de outros factores que podem contribuir para o entendimento desta situação, este artigo irá centrar a sua atenção na dimensão política do problema, por entendermos que aí se situa o cerne dos problemas. Neste sentido: as políticas desenhadas, desde o I Governo Constitucional, para a comunicação social e regional não têm incentivado a procura da qualidade, mas antes a manutenção da mediocridade. Mais: em vez de falarmos na tomada de decisões, talvez seja mais relevante referir as não-decisões, tão escassas são as medidas que, no seu conjunto e pelo seu alcance, deixam antever a definição clara de uma política para o sector. As leituras indicam-nos que o trabalho de Steven Lukes ("Power: a Radical View") sobre a tomada de decisão é decisiva para tentarmos sustentar minimamente a hipótese que nos guiará ao longo do ensaio: "Mais do que incentivar o desenvolvimento da imprensa local e regional, as políticas - ou a falta delas - definidas para este sector pelos vários Governos têm coarctado a sua evolução".

Esta discussão é tanto mais relevante quanto se sabe que o anterior e o actual Governos (os XV e XVI Governos Constitucionais formados pela coligação PSD/ CDS-PP) têm vindo a prometer a realização de uma verdadeira reforma estrutural no sector. Mas não a queríamos iniciar sem falarmos das características da imprensa local e regional. Parece-nos igualmente relevante tentar avaliar o seu papel no mundo globalizado de hoje. Antes de descermos à análise das decisões mais importantes para o sector, olharemos para o que têm sido as linhas mestras das políticas de comunicação em Portugal, no sentido de tentarmos entender se a imprensa local e regional também lá está, ou se passou completamente ao lado desses momentos-chave.

Agarraremos depois aquelas que nos parecem ser as duas decisões mais relevantes sobre o sector - elaboração do Estatuto da imprensa local e regional e decisão de reduzir o porte-pago de que beneficiava, até aí a 100\%, a maioria dos títulos - para entender quem foram os actores e que movimentações encetaram para alcançar os objectivos.

Dada a amplitude da reforma prometida pelo anterior e pelo actual Executivo, lançaremos um olhar sobre o que é até agora conhecido, para tentar perceber se, de facto, as prioridades e o processo de decisão se inverteram.

Só então arriscaremos dizer alguma coisa na conclusão do ensaio.

\section{0 conceito (possível) de imprensa local e regional}

A imprensa local e regional tem - ou deve ter - como objectivo primeiro a recolha, tratamento e divulgação de factos noticiosos que ocorrem na sua área de implantação, seja ele concelhia, distrital ou regional.

Mas se é relativamente simples definir empiricamente a imprensa local e regional, é bem mais complicado alcançar um conceito cientificamente consistente. Desde logo, porque tal tarefa só seria possível conhecendo ao pormenor as características intrínsecas do sector. Quem são as pessoas e os jornalistas que fazem estas publicações? Qual é a sua média de idades e que graus de qualificação possuem? Em que circunstâncias são 
os jornais feitos? Que grau efectivo de intervenção e interacção têm as publicações nas comunidades? Não há respostas porque não existem trabalhos sobre estas matérias. $\mathrm{O}$ que suscita, desde logo, uma questão: sem conhecer o âmago da imprensa local e regional, sobre que bases foram delineadas as políticas para este sector da comunicação social portuguesa?

As dificuldades na definição do conceito são, de resto, bem patentes se analisarmos as leis de imprensa que foram sendo publicadas. "A legislação portuguesa tem definido e redefinido imprensa regional e local ao longo da sua história, permanecendo, no entanto, um conceito científico difícil”, reconhece o presidente da AIND, João Palmeiro 7.

Em 1971, por exemplo, dizia-se que a "imprensa regional é constituída pelas publicações periódicas não diárias que tenham como principal objectivo divulgar os interesses de uma localidade, circunscrição administrativa ou grupos de circunscrição vizinhos”. Assumia-se, portanto, que não haveria jornais locais e regionais diários e que a delimitação do seu âmbito era feita de acordo com um critério geográfico.

A Lei de Imprensa de 1975 escolhe o critério da expansão para dizer que “as publicações periódicas podem ser de expansão nacional e regional, considerando-se de expansão nacional as que são postas à venda na generalidade do território". Por exclusão de partes, percebe-se que as publicações de "expansão regional" têm o seu nicho de território.

É em 1988 que se publica o Estatuto da Imprensa Regional (Decreto-Lei 106/88, de 16 de Março). Ao âmbito geográfico somam-se referências aos conteúdos e à independência em relação ao poder político. Assim, considera-se "imprensa regional todas as publicações periódicas de informação geral, conformes à Lei de Imprensa, que se destinem predominantemente às respectivas comunidades regionais e locais, dediquem, de forma regular, mais de metade da sua superfície redactorial a factos ou assuntos de ordem cultural, social, religiosa, económica e política a elas respeitantes e não estejam dependentes, directamente ou por interposta pessoa, de qualquer poder político, inclusive o autárquico”.

\section{A Lei de Imprensa de 1999 recolhe na essência o que consta do Estatuto}

O Estatuto merecerá uma posterior e mais cuidada análise. Para já, importa assinalar que, seja qual for a definição adoptada, todas elas identificam um traço inequívoco deste tipo de publicações: a "linguagem de proximidade" a que todos eles recorrem como elemento distintivo da chamada imprensa nacional ${ }^{8}$. E talvez seja esse critério que nos permite ver este género de imprensa como um facto social da maior relevância. "A imprensa local participa nas tarefas de definição e formação da identidade e

\footnotetext{
7 "Imprensa regional em Portugal - que futuro"?, Anuário Obercom 2001-2002, pp. 167-202

${ }^{8}$ É relevante notar aqui que praticamente toda a grande imprensa nacional tem feito nos últimos anos um esforço para também ir ao encontro do "jornalismo de proximidade". O Jornal de Notícias, por exemplo, criou edições próprias para as regiões Centro e Minho, além de possuir edições diferenciadas para o Grande Porto e Grande Lisboa/Sul. Da mesma forma, o Público avançou com edições diferenciadas no Minho e Centro. No Minho, o projecto já foi abandonado. Mas a nota mais saliente talvez seja mesmo o acordo que o Expresso recentemente estabeleceu com jornais regionais de todo o
} 
mudança da sociedade de que é fruto e alimento" (Alves, 1990:236). Há quem vá ainda mais longe. “À comunicação social local e regional cabe a insubstituível tarefa de promover o envolvimento do cidadão comum nos processos de decisão, através de um incentivo do conhecimento, discussão, diálogo e defesa dos pontos de vista das populações; o fomento de um poder de autogestão responsável; e a defesa de um desenvolvimento equilibrado das diferentes regiões"" (Esteves, 1990:4).

Para Carlos Camponez, “as especificidades da imprensa regional e local resultam, fundamentalmente, do seu compromisso com a região e do seu projecto editorial. É nesse compromisso que frutifica ou fracassa, se diversifica ou homogeneíza a comunicação" (Camponez, 2002:103).

Xosé López Garcia et al. (1998) alarga ainda mais o âmbito da importância da imprensa regional e local. "Os meios locais apresentam-se como o resultado de uma reunião na qual a comunidade em conjunto discute temas do seu interesse. O espectador estará sendo interpelado como cidadão mais do que como consumidor. É aí onde a comunicação local tem que jogar as suas cartas no nível social, político e económico. A pluralidade de vozes, também no âmbito local, é um elemento essencial da democracia”.

\section{10 (mau) exemplo português}

Resta saber se, pela análise do dados disponíveis sobre a realidade do sector em Portugal, poderemos alcançar um conceito de imprensa local e regional capaz de se aproximar destas funções.

Os dados disponíveis no Instituto de Comunicação Social mostram o seguinte:

i) há novecentos títulos de publicações periódicas;

ii) o número de jornais diários não ultrapassa os trinta;

iii) a periodicidade mais comum é a mensal, seguida da semanal;

iv) o conjunto de tiragens médias situa-se perto dos 4500 exemplares. Metade dos jornais com direito a porte-pago (645 no total) não vai além dos 2500 exemplares;

v) só $8 \%$ dos jornais tem tiragens acima dos dez mil exemplares;

vi) só $23 \%$ das empresas jornalísticas tem contabilidade organizada;

vii) só dez empresas ultrapassam os cem mil contos de vendas anuais de publicidade.

No documento que serviu de base à apresentação da reforma dos media regionais, o secretário de Estado com a tutela do sector no XVI Governo Constitucional,

país para se tentar expandir nos distritos onde menos vende. Do acordo resultou, entre outras coisas, a partilha de notícias entre o semanário nacional e os jornais regionais ("Expresso junta-se a jornais regionais para formar "clube". Despacho da Agência Lusa, de 11 de Setembro de 2003).

${ }^{9}$ Afastada a regionalização, a discussão sobre as assimetrias regionais está hoje novamente em voga com a criação de comunidades urbanas no âmbito da reorganização territorial posta em marcha pelo Governo. 
Feliciano Barreiras Duarte, divulgou mais dados - uns actualizam os do ICS e outros são novos e relevantes.

Assim:

i) a maioria dos jornais tem uma situação económica débil;

ii) a tiragem média é de quatro mil exemplares;

iii) a periodicidade mais frequente é a mensal (43\%), seguida da semanal (30\%) e da quinzenal $(23 \%)$;

iv) apenas $15 \%$ da tiragem é vendida em banca;

v) 281 dos títulos que recebem porte-pago não têm um único profissional com contrato de trabalho.

Não é, de facto, um retrato famoso. Um estudo elaborado por Paulo Faustino ${ }^{10}$ acentua ainda mais esta realidade, ao mostrar que, de 134 jornais regionais e locais analisados, 43,4\% não vende mais que duzentos exemplares nas bancas. Mais: 36,2\% fazem chegar aos "leitores", através da assinatura, entre dois mil e quatro mil exemplares. A maior parte dos jornais analisados $(28,8 \%)$ tira entre três mil e cinco mil exemplares - ou seja, as tiragens são correspondentes a populações locais e não regionais. E a maior parte também são semanários $(38,1 \%)$ e quinzenários $(31,3 \%)$.

É possível, agora, ensaiar uma curta definição da imprensa regional e local portuguesa. Trata-se de uma imprensa empresarialmente muito frágil, com grandes dificuldades para chegar aos seus leitores, muito pouco atractiva e ainda menos arrojada. Há, felizmente, alguns exemplos de bons jornais e grupos de comunicação em algumas regiões do país (Leiria e Coimbra, por exemplo), mas tratam-se de excepções que apenas confirmam a regra. O que significa que estamos longe de poder falar de um sector capaz de cumprir com eficácia e arrojo essa "tarefa insubstituível de promover o envolvimento do cidadão comum nos processos de decisão, através de um incentivo do conhecimento, discussão, diálogo e defesa dos pontos de vista das populações”, para retomar o conceito de João Pissarra Esteves.

\section{Globalização: riscos e desafios}

Não nos atreveremos a discutir aqui o fenómeno da globalização, mas parece-nos que a sua marcha coloca desafios sérios à imprensa local e regional, pelo que tentaremos perceber que papel pode ela desempenhar num mundo em que a perda das grandes narrativas nos empurrou rapidamente para um estado em que o apetite pelo acessório ganhou muito terreno ao debate sobre o essencial.

Há abordagens múltiplas sobre os efeitos no espaço público de uma cultura - a nossa - que é cada vez mais globalizadora e pós-moderna. A facilidade de linguagem

\footnotetext{
10 "A imprensa regional em Portugal: o estado da arte e práticas de gestão", disponível no site www.obercom.pt. Paulo Faustino foi assessor da Administração do Grupo Lusomundo e é o actual adjunto de Feliciano Barreiras Duarte.
} 
de Gilles Lipovetsky, contudo, ajuda-nos a perceber rapidamente as consequências que a “época do deslizar”, para usar uma expressão que lhe é tão grata, tem nas nossas vidas.

O que é, afinal, a “época do deslizar”? Trata-se de uma metáfora feliz a que Lipovetsky recorre para ilustrar um tempo, que é o nosso, "em que a res publica não tem qualquer elo sólido, qualquer ponto de ancoragem emocional estável. Hoje, as questões decisivas da vida colectiva conhecem o mesmo destino que os êxitos dos tops, todos os pontos altos se desmoronam, tudo desliza e se apaga numa indiferença descontraída" (Lipovestky, 1989: 14). Aquilo que se procura é o mínimo de austeridade e o máximo de desejo.

Há uma questão política da máxima relevância que aqui se joga: a "desmobilização do espaço público" é consequência do declínio dos ideais e valores que cedem o lugar ao interesse próprio, à “demanda do ego", ao "êxtase da libertação pessoal”, à obsessão pelo corpo, ao "hiper-investimento no privado". "O homem indiferente não se apega a nada, não tem uma certeza absoluta, está preparado para tudo e as suas opiniões são susceptíveis de modificações rápidas”, escreve Lipovetsky, que a seguir reclama o sociólogo norte-americano Daniel Bell para sublinhar o ponto. Aos olhos de Bell, o hedonismo das sociedades pós-modernas tem como "efeito inelutável a perda da civitas, o egocentrismo e a indiferença pelo bem comum, a ausência de confiança no futuro, o declínio da legitimidade das instituições. Valorizando excessivamente a busca da auto-realização, a era do consumo mina o civismo, sapa a coragem e a vontade, deixa de proporcionar qualquer valor superior ou razão de esperança”.

É esta deriva pós-moderna e globalizadora que de alguma forma reintroduz a importância das identidades culturais e das comunidades locais no debate. É nesse plano de análise que se pode interpretar, por exemplo, a opinião de Anthony Giddens sobre esta matéria. “A globalização não se limita a empurrar para cima, também puxa para baixo, criando novas pressões para a concessão de autonomias locais. Daniel Bell descreve muito bem a situação quando diz que os países se tornam demasiado pequenos para solucionarem os problemas grandes, mas também demasiado grandes para solucionarem os problemas pequenos. A globalização é a razão que leva ao reaparecimento das identidades culturais em diversas partes do mundo" (Giddens, 2000: 24).

Moragas Spà, citado por Rui Cádima, nota, por seu turno, que “a nova sociedade de informação não é uma sociedade transnacional mas antes, mais exactamente, uma sociedade ao mesmo tempo 'local' e 'global'” (Cádima, 1999: 13). Rui Cádima pega no pensamento de Spà e sublinha a importância de um conceito que convém reter: o da "glocalização". E para dizer o quê? Para dizer, recorrendo a Lévy-Strauss, que, "quanto menor for a possibilidade de as culturas locais receberem, de fora, aspectos da cultura universal, menos serão capazes de compreender a sua própria identidade, enfim, a especificidade que lhes dá a sua diferença” (idem, ibidem: 17).

Ora, a discussão sobre as identidades culturais far-se-á tanto melhor quanto maior - e melhor também - for a informação disponível junto das comunidades locais e regionais. Nesse desejo de regresso aos espaços públicos tal e qual Habermas os con- 
cebia, os media regionais não podem deixar de ter um papel de enorme relevância. "A leitura de um jornal regional/local é importante para nos devolver o 'sentimento de comunidade'. Não poderemos nunca fazer parte da vida social sem estarmos a par da actualidade" (Mathien, 1983: 42, 43).

"O jornalismo que se pratica fora dos grandes meios urbanos pode ser um elemento estruturador desse espaço público regional entendido como esfera crítica de debate e de interacção dos cidadãos em torno dos problemas que lhe são próximos", entende, por seu turno, João Carlos Correia ${ }^{11}$. "Os media regionais podem comportar um movimento dirigido em dois sentidos. Por um lado, são instância de reforço da identidade das comunidades com que se relacionam. Por outro, são espaços de uma potencial 'abertura ao mundo'", acrescenta.

Este reforço do sentimento de pertença parte já do pressuposto de que a "aldeia global” de McLuhan não é mais discutível - impôs-se como facto incontornável. Discutíveis são as formas de nos mantermos "vivos" dentro dela. De evitar os efeitos da homogeneização da vida social e da desterritorialização ${ }^{12}$. Não se defende aqui que a imprensa local e regional ajude a construir um "bunker" em relação ao que se passa "lá fora", no mundo. O que ela deve fazer, isso sim, é ajudar a entender o que o mundo traz de novo, mas sublinhando sempre a importância das identidades culturais como cimento de um modelo que, para seguir a proposta de Roland Robertson, assente na "localização da globalidade". Isto é: o local não é indiferente ao global, mas consegue fazer uma triagem do que interessa, única maneira de construir uma sociedade "local/global" sem espezinhar as identidades. E nesta construção tem seguramente a imprensa local e regional um papel importantíssimo a prestar.

É nesse sentido, por exemplo, que segue o pensamento de Bel Mallen. O autor "desenvolve toda uma teoria sobre o direito da informação local que se organiza não tanto na oposição, pura e simples, à globalização, mas como um espaço de criação de alternativas" (Camponez, 2002: 149, 150). Trata-se de "permitir uma identidade aos indivíduos e às culturas na sociedade de massa, seguindo o princípio de que não faz sentido pensar as comunidades locais sem comunicação e informação local. Como que parafraseando [Daniel] Bougnoux quando afirma: 'a comunicação destina-se, em primeiro lugar, a organizar a relação social, a estruturar a vida quotidiana e a manter a coesão da comunidade" (idem, ibidem).

Não estamos a falar de um problema pequeno, quando falamos da criação de alternativas que a informação local e regional pode sugerir e da consequente defesa das identidades individuais e comunitárias. "A perda e consequente complexificação das identidades (...) é, talvez, o problema sociológico mais sério da modernidade, tanto no tocante à auto-definição dos sujeitos, como no que respeita à tipificação e classificação de que são objecto por parte de outros. A 'repatriação da diferença',

\footnotetext{
11 "Jornalismo e Espaço Público", Dissertação de Mestrado, Universidade da Beira Interior.

12 "A desterritorialização é o maior impacto cultural da conectividade global. Mas essa conectividade também fornece às pessoas um recurso cultural que não possuíam antes da sua expansão: uma consciência cultural que é, em vários sentidos, global". (Tomlinson, 1999:30)
} 
como se exprime Appadurai, ou a sua equivalente 'reterritorialização', como prefere Boaventura S. Santos, não são senão manifestações da procura de sentido de lugar que indivíduos, grupos e movimentos sociais buscam conferir às suas identidades e às suas subjectividades, ambas em risco de descaracterização pela globalização da sua vida" (Fortuna, 1999: 16).

Considerados os efeitos da globalização e da pós-modernidade, há uma coisa que é certa: "A ideia de um espaço público moderno e a ideia pós-moderna do fim do sujeito são intrinsecamente irreconciliáveis” (Esteves, 2003: 105). É por isso que aqui defendemos a importância da imprensa local e regional como um instrumento (porventura decisivo) susceptível de ajudar a criar um renovado espaço público nas comunidades, modo de assegurar que as identidades não se diluem - as pessoais e as comunitárias.

\section{Parente pobre das políticas de informação}

Tentámos, no último capítulo, situar a importância da imprensa regional e local no contexto da globalização e da pós-modernidade. Achámos que o exercício valia a pena por duas ordens de razões. Primeiro, porque se ficou, como esperamos, minimamente provada a sua relevância, temos mais um argumento para notar as consequências da clivagem entre as capacidades da imprensa local e regional portuguesa e as suas actuais características (avaliação feita no ponto 2). Segundo, porque o debate travado no ponto 3 nos serve também de lançamento para a problemática que agora gostaríamos de discutir. E que é esta: que lugar tem ocupado a imprensa local e regional no âmbito das políticas de informação em Portugal? Para tentar obter a resposta faremos uma incursão, necessariamente breve, pelo que têm sido essas políticas.

A primeira constatação é emblemática. As políticas definidas logo após a revolução de 1974 mantiveram-se, grosso modo, até meados da década de 80. "Este aspecto sugere que a natureza autoritária dos governos provisórios de Esquerda serviu aos recém-criados democratas. Apesar da Constituição de 1976 (com a sua impressionante exibição de liberdade civis), nenhum Governo eleito estava preparado para garantir a liberdade de imprensa. Genericamente, seguindo as medidas políticas introduzidas durante o período revolucionário, políticos de todas as filiações não desenharam políticas para os media mas tomaram meramente os necessários passos para garantir que os media nacionalizados fossem favoráveis a quem estivesse no Poder" (Sousa, 1999: 3, 4).

Em bom rigor, significa isto que as condições políticas no período que se estendeu desde a "revolução dos cravos" até à constituição, em 1987, do primeiro Governo maioritário aconselhavam a que o discurso liberalizador - e até libertador - não tivesse correspondência na realidade. A Lei de Imprensa de 1975 e a Constituição de 1976 são bons exemplos. Ambas sublinhavam a necessidade de acabar com a censura e garantir a liberdade de imprensa, mas "se esta visão foi bem sucedida em termos legais, uma bem diferente e não expressa política estava a ser implementada” (idem, ibidem). Estribado no perigo que as "forças reaccionárias" ainda representavam, o Movimento das Forças Armadas decidiu que os media teriam que ser controlados durante, pelo 
menos, o "período revolucionário". A imprensa que se mantinha nas mãos de privados foi toda nacionalizada.

As mudanças de fundo no panorama dos media portugueses aconteceram em 1987, com a chegada do primeiro Governo maioritário de Cavaco Silva. "A percepção da inevitabilidade das reformas estava relacionada com factores externos e internos. Nos anos 80, ocorreram na Europa importantes mudanças que iriam ter um claro impacto em Portugal. A televisão e a rádio estavam, até então, concentradas nas mãos do Estado. A noção de serviço público na esfera mediática foi dominante durante décadas e, salvo raras excepções, não era permitida a entrada de actores privados nos media electrónicos. Esta tradição europeia - bem distinta da norte-americana - foi claramente posta em causa e as pressões para abrir o mercado a novos actores intensificaram-se" (Sousa, 2001:2).

Em Portugal, a estabilidade política, aliada ao crescimento económico, tornou "cada vez mais difícil justificar a forte concentração dos media e das telecomunicações nas mãos do Estado". O Governo social-democrata da altura decidiu "privatizar a imprensa que havia sido nacionalizada no período revolucionário, liberalizar o sector radiofónico, privatizar a Rádio Comercial e abrir a televisão à iniciativa privada” (idem, ibidem), sendo que esta última foi, sem dúvida, a medida mais marcante dos Governos de Cavaco Silva na esfera mediática. Ainda assim, o Estado manteve - e continua a manter - sob o seu domínio a Agência Lusa.

Esta pulsão liberalizadora - "Em dez anos, praticamente nada tinha sido feito para alterar este quadro verdadeiramente anacrónico nas democracias europeias e claramente redutor de uma efectiva liberdade de expressão e de informação" (Silva, 1995:21) - não teve, contudo, paralelo na imprensa local e regional. Bem pelo contrário: o Governo optou por manter a distribuição de apoios e incentivos como a medida política estruturante para os media regionais. "Ao longo destes anos, foram já mais de quatrocentos os jornais beneficiados, e os projectos de investimento concretizados permitiram que hoje, de forma objectiva e inegável, o País disponha de uma imprensa regional de melhor qualidade, mais pujante e com crescente afirmação social e cultural” (Silva, 1995: 24).

Não espanta que assim seja. "Em termos de imprensa, nenhuma atenção é prestada ao que vai acontecendo a nível local e regional. O poder político, em Portugal, é tradicionalmente muito centralizado, o que tem sido em parte causa e consequência das enormes assimetrias regionais entre o interior e o litoral. As autoridades públicas não têm tido qualquer política para lutar contra a desertificação humana e a pobreza nas áreas rurais do interior. Por isso, a imprensa regional e local tem uma qualidade muito pobre, quase não tem jornalistas profissionais e, genericamente, sofre de severas dificuldades financeiras" (Sousa, 1994:2).

Este estado de coisas não mudou especialmente quando, em 1995, António Guterres (então líder do Partido Socialista) sucedeu a Cavaco Silva na liderança do Governo. $\mathrm{O}$ que faz algum sentido, dado que, "quando António Guterres chegou ao Governo, as reformas estruturais no sector televisivo, radiofónico e na imprensa tinham já sido executadas” (Sousa, 2001:5). De resto, no conjunto de medidas proposto pelo Execu- 
tivo socialista apenas uma - e recorrente - diz respeito aos media regionais: "alargar às rádios locais o sistema de incentivos actualmente existente para a imprensa regional”.

As coisas mudariam um pouco no segundo mandato de António Guterres, como veremos mais adiante. Mas fica, parece-nos, bastante evidente que a imprensa local e regional foi desde o dealbar da democracia portuguesa uma espécie de parente pobre das políticas de informação dos vários Governos. Tentaremos sublinhar ainda mais esta evidência já de seguida, ao analisarmos as decisões mais relevantes tomadas sobre a imprensa local e regional.

\section{0 exercício da decisão}

Antes de partirmos para a análise das decisões tomadas pelos vários Governos no que diz respeito a este sector, importa, contudo, perceber do que falamos quando falamos da tomada de decisões. O que é, afinal, decidir? E, num processo de tomada de decisões, que valores e circunstâncias fazem pender a balança para um dos lados e não para o outro? A não tomada de decisões pode, por outro lado, ser ela mesma uma decisão? Quem intervém no processo decisório e quem tem poder para, por fim, tomar as decisões?

$\mathrm{O}$ interesse pelo estudo das decisões tem em Herbert Simon um dos principais percursores. Logo a seguir à II Guerra Mundial, Simon procurou mostrar que os modelos matemáticos usados até então para estudar as decisões eram insuficientes, advogando que o importante é analisar o indivíduo (o decisor) e a organização onde ele se insere. Por isto: na medida em que a decisão contém em si uma proposta de acção, ela perceber-se-á tanto melhor quanto melhor pudermos identificar os actores nela envolvidos.

Ou seja: a decisão não é mais que "o instante final de um processo que se inicia um tempo antes, muitas vezes num momento difícil de identificar. Esse momento é aquilo a que muitas vezes se chama o estímulo da decisão" (Camões, 1997: 81). Podemos igualmente falar de um "conjunto de acções e factores dinâmicos que começa com a identificação de um estímulo para a acção e termina com o consenso ou envolvimento para a acção" (idem, ibidem). Importa reter nestes conceitos uma outra variável. É que, havendo muitos intervenientes no processo de decisão, os factores externos são inequivocamente relevantes. "O ambiente muitas vezes pode também decidir” (idem, ibidem).

Simon identificou dois tipos de decisões: programadas ou de rotina e não programadas. A tipologia clássica opta por uma classificação que nos parece mais rigorosa:

i) decisões estratégicas (grande impacto a longo prazo, envolvendo muitos membros e todos os níveis organizacionais);

ii) decisões tácticas (impacto de médio prazo);

iii) decisões operacionais (impacto de curto prazo).

Para a discussão que nos interessa aqui levar a cabo deve acrescentar-se a importância dos aspectos políticos na tomada de decisão: os jogos de poder, os grupos de influência, os lobbies e a defesa dos seus interesses. Veremos mais à frente como uma 
das principais decisões sobre a imprensa regional - o corte no porte-pago - tem todos estes condimentos.

\section{1.0 contributo de Lukes}

Se o trabalho de Herbert Simon é importante pela sua componente pioneira, o contributo que Steven Lukes deu para o entendimento da tomada de decisões no âmbito do exercício do poder é igualmente de enorme relevância.

A primeira constatação de Lukes é esta: para perceber o exercício do poder, não basta analisar as práticas facilmente observáveis, como fazem os defensores das teorias do Estado. ${ }^{13}$ A tese de Lukes é a de que o poder tem três dimensões.

i) Visão unidimensional. A análise dos processos de decisão faz-se através do estudo do comportamento dos vários protagonistas sociais. O que interessa é perceber quem impôs o seu ponto de vista e por que razão o conseguiu impor ${ }^{14}$. Ou seja: só podemos chegar a conclusões quando o conflito e a luta pelo exercício do poder são abertos e observáveis.

ii) Visão bidimensional. O poder tem duas faces: a tomada de decisões e a não tomada de decisões. Neste último caso, evita-se a acção sobre questões em relação às quais não importa decidir, maneira de afastar da agenda pública as matérias mais complexas e problemáticas para o exercício do poder.

iii) Visão tridimensional. Nas duas visões anteriores, a noção de conflito está sempre presente. Ora, a melhor forma de exercer o poder passa por eliminar o conflito, estágio a que corresponde justamente a visão tridimensional.

A nossa proposta inicial passava por considerar que a imprensa regional e local de Portugal tem sido vítima da não tomada de decisões. O que nos obriga, tendo por certo que a sua operacionalização em termos científicos não é fácil, a olhar com um pouco mais de cuidado para as não decisões.

Lukes recorre aos trabalhos de Bachrach e Baratz ${ }^{15}$ e de Matthew Crenson ${ }^{16}$ para nos explicar que estamos perante um processo em que "os pedidos de mudança (...) podem ser sufocados mesmo antes de serem verbalizados. Ou 'mortos' antes de subirem à arena da tomada de decisões. Ou, falhando todas estas coisas, destruídos durante o estágio da tomada de decisões no processo político” (Lukes, 1974: 18, 19).

\footnotetext{
${ }^{13}$ Elas dividem-se em três ramos fundamentais. Pluralismo: o poder está disperso pelos múltiplos grupos sociais. O Estado gere os conflitos da sociedade civil e as suas decisões reflectem os interesses desses vários grupos. Robert Dahl é o autor que mais se bateu por esta ideia. Elitismo: a história política é a história do domínio das elites. Os grandes objectivos das sociedades são estabelecidos e manipulados pelas elites. Mills é o autor de referência desta linha. Corporativismo: no sistema de representação de interesses, as diversas partes estão organizadas de uma forma não competitiva pelo Estado. Schmiter é o percursor desta ideia.

${ }^{14}$ Esta concepção bebe muito na ideia formulada por Max Weber, que entende o poder como "a capacidade de obrigar os outros a adoptar um certo tipo de comportamento" (Moreira, 1989: 72).

15 "The two faces of power", American Political Science Review, 56 (1992), pp. 947-52.

16 "The un-politics of air pollution: a study of non-decision making in the cities" (1971), Baltimore e Londres: The Johns Hopkins Press.
} 
Do que se trata, no fundo, é de reconhecer que estamos perante assuntos de fronteira no espectro político. Ora, Bachrach e Baratz consideram fundamental identificar essas questões, na exacta medida em que a sua não colocação na agenda pode dizer muito do poder político em causa e dos interesses que giram em torno de si.

Mais: para os mesmos autores, a ideia dos pluralistas de que o poder na tomada de decisões só é observável quando o conflito é aberto também se aplica à análise das não-decisões. "Se não há conflito, aberto ou encoberto, a presunção só pode ser a de que há um consenso, caso em que a existência de não-decisões é impossível”, escrevem os autores, citados por Lukes (Lukes, 1974: 19).

Matthew Crenson é ainda mais lapidar. A sua tese é basicamente esta: a análise das não-decisões é mais relevante do que a análise das decisões, visto que estas não nos dizem nada sobre os grupos e os problemas que foram postos de lado na vida política de uma determinada comunidade. A sua perspectiva agrada a Lukes, que a cataloga como estando na fronteira entre as segunda e terceira dimensões do poder.

Seja como for, Steven Lukes prefere aquilo a que chama uma concepção "radical” do poder, que tende para a eliminação do conflito no exercício do mesmo. As leituras feitas sugerem-nos outra ideia, que tentaremos aprofundar na conclusão do trabalho: no caso dos media regionais e locais em Portugal, o exercício da não-decisão não é paradoxal relativamente à eliminação do conflito no exercício do poder. É complementar.

\section{Pela política dentro}

Defendemos no início do trabalho que as decisões mais relevantes e de carácter estritamente político tomadas até hoje no que diz respeito aos media regionais e locais se prenderam com a elaboração do Estatuto da Imprensa Regional e com o corte no porte-pago. Tentaremos agora sustentar esta ideia.

A análise cuidada de todos os programas dos vários Governos constitucionais desde o 25 de Abril até hoje é um bom ponto de partida. Desde logo, porque nos ajuda a elucidar a questão central deste ensaio. Com mais ou menos espaço nos vários Diários da República onde os programas são publicados, há um fio condutor claro e evidente nas preocupações dos executivos: apoiar sempre, através da atribuição de subsídios, a imprensa regional e local.

Curiosamente, é no I Governo Constitucional, cujo programa foi publicado em 1976, que se elabora, em 44 linhas, aquilo que podemos considerar o esboço de uma política: avalia-se o estado da imprensa regional, definem-se objectivos e atribuem-se meios (ou, pelo menos, declara-se essa intenção). Seja como for, o essencial da preocupação está na "revisão, dentro das disponibilidades orçamentais, do esquema de apoio à imprensa regional, tanto quanto possível no sentido do reforço desse apoio”.

Já o II Governo Constitucional dedica umas paradigmáticas quatro linhas à imprensa regional, para sublinhar outra vez a necessidade de "esquemas de apoio".

No programa do III Governo Constitucional o sector recupera alguma importância no conjunto das preocupações dos decisores. Está lá, antes de mais, a necessidade dos apoios, mas avançam-se outras ideias, designadamente “a implantação, em pólos de 
desenvolvimento, de parques gráficos" e o "estabelecimento, nas capitais de distrito, de centros de apoio técnico à transmissão de material informativo para os órgãos de comunicação social”. E ainda a "organização de iniciativas pedagógicas, em colaboração com a futura escola superior de jornalismo, visando o aperfeiçoamento profissional dos colaboradores da imprensa regional”.

O programa do IV Governo Constitucional nem uma só referência faz aos media regionais e locais. $\mathrm{O} \mathrm{V}$, em três linhas, volta a falar da necessidade de os apoiar. Tão-só. O mesmo sucede nos VI, VII e VIII Governos Constitucionais. Nos IX e X, nem uma linha se encontra sobre a imprensa regional e local.

\section{1. Um estatuto equívoco}

É no XI Governo Constitucional - o segundo dos Governos de Cavaco Silva - que se decide aprovar o Estatuto da Imprensa Regional (Decreto Lei n. ${ }^{\circ}$ 106/88, de 31 de Março), “através do qual o Governo reconheceu formalmente o inegável interesse público deste sector da comunicação social” (Silva, 1995: 24). O que se pretendia com o Estatuto? "Consagrar, de modo explícito, o apoio do Estado à afirmação da imprensa regional, designadamente pela criação de instrumentos de ajuda à reconversão tecnológica e modernização das suas estruturas e equipamentos. Ao longo destes anos, foram já mais de 400 os jornais regionais beneficiados, e os projectos de investimento concretizados permitiram que hoje, de forma objectiva e inegável, o País disponha de uma imprensa regional de melhor qualidade, mais pujante e com crescente afirmação social e cultural" (idem, ibidem).

Há três reparos que, a nosso ver, ajudam a perceber o que está por detrás desta decisão.

i) O Estatuto contém um erro susceptível de desvirtuar as boas intenções do Governo de Cavaco Silva. É que a definição de imprensa regional constante do Estatuto, a partir da qual se lançam as bases para esta "política”, confunde conceitos básicos, deixando antever o pouco cuidado posto na elaboração do mesmo e, sobretudo, a pouca informação sobre a realidade dos media regionais e locais.

De facto, a definição mete no mesmo saco realidades distintas. Um semanário que, por exemplo, se edita num determinado concelho de Trás-os-Montes mas que cobre, com o contributo de jornalistas profissionais, os distritos de Vila Real e Bragança, não é igual a um outro que, apesar de editado no mesmo concelho, publica apenas e só notícias dessa localidade e sem o contributo de jornalistas profissionais. As duas realidades, tendo embora pontos de encontro, são estruturalmente distintas. E, sendo assim, talvez mereçam "políticas” distintas.

ii) Na mesma altura da publicação do Estatuto, a tutela do sector estava entregue a Marques Mendes, então secretário de Estado-adjunto do ministro-adjunto para os Assuntos Parlamentares. Ora, Marques Mendes, em 1987, no encerramento do II Congresso da Associação de Imprensa Não Diária, tinha sobre a imprensa regio- 
nal e local esta visão: “A imprensa regional assume-se por mérito próprio, com a carolice, o salutar amadorismo e a invulgar dedicação que são próprios de quem sente, com sinceridade, o que vive, o que exerce, o que faz e o que realiza" ${ }^{17}$. Está bom de ver que o "salutar amadorismo" não pode bater certo com a "imprensa regional de melhor qualidade, mais pujante e com crescente afirmação social e cultural" que Cavaco Silva, primeiro-ministro, vislumbrava.

iii) De resto, o comentário de Cavaco Silva ao Estatuto é elucidativo quanto à visão que o Governo de então tinha sobre os media regionais e locais. Por isto: porque nos parece muito redutor considerar que a atribuição cega de subsídios possa ser considerada uma política.

Ficámos no XI Governo Constitucional. O XII - último de Cavaco Silva - nada de relevante acrescentou à questão. O programa do XIII Governo Constitucional - o primeiro de António Guterres - também não traz nada de novo. É, porém, no seu segundo Governo de Guterres (XIV Constitucional) que se tomará a decisão que, provavelmente, mais abalou o sector dos media regionais e locais desde o 25 de Abril.

\section{2. Porte-pago: ondas de choque}

Quando assumiu, em 1995, o lugar de secretário de Estado da Comunicação Social no primeiro Governo de António Guterres, Alberto Arons de Carvalho encontrou "um sector que, a par com alguma gente nova com arrojo e com ideias, tinha muita gente acomodada, muita gente que estava à frente de jornais regionais para manter uma tradição familiar, sem nenhuma visão empresarial" ${ }^{18}$.

Mais do que isso: "Também tive a noção de que havia um sistema de auxílios do Estado que afastava a imprensa regional da procura da qualidade. O porte-pago a $100 \%$ fazia com que houvesse muitos jornais que tinham uma tiragem ditada pela relação com os anunciantes e não pela relação com os leitores. Eram jornais praticamente gratuitos, em grande parte" ${ }^{19}$. "Chegava a ser assustador. As pessoas viajam pelo país, vão aos quiosques comprar os jornais nacionais e não encontram o jornal da terra. Como o porte-pago permitia que a distribuição fosse toda feita, de borla, pelo correio, os jornais locais não tinham visibilidade" nas bancas.

E mais ainda: "Havia uma fraude generalizada em relação ao porte-pago. Do ponto de vista das contas do Estado, fomos verificando que havia desde os tempos do Governo anterior pelo menos uma suborçamentação: o Orçamento de Estado previa seiscentos mil ou setecentos mil contos para o porte-pago e ele custava dois milhões.

\footnotetext{
17 “II Congresso da Associação de Imprensa Não Diária - Aposta no Futuro”, Lisboa, 1998.

${ }^{18}$ As citações usadas doravante e atribuídas a Arons de Carvalho resultam de uma entrevista feita em Dezembro de 2001, no gabinete do secretário de Estado, no âmbito da recolha de materiais para a elaboração de uma tese de mestrado sobre esta matéria. A reprodução do conteúdo da entrevista está devidamente autorizada.

${ }^{19}$ Hoje, o conjunto de incentivos do Estado à comunicação social está dividido em dois: incentivos directos (modernização tecnológica; formação e qualificação profissional; criação de conteúdos na Internet; inovação e desenvolvimento empresarial; incentivos específicos; e incentivos à edição de obras sobre comunicação social) e incentivos indirectos (porte-pago). O porte-pago leva, de longe, a fatia de leão (ver Quadros I e II).
} 
Depois passou a custar mais de três milhões e no Orçamento de Estado nunca pudemos pôr mais de um milhão. O Ministério das Finanças, por uma razão de equilíbrio, não aceitava dar mais, preferia ficar a dever aos CTT. Além disso, quando dizíamos ao Ministério das Finanças 'isto não chega', recebíamos como resposta: 'ponham mais, mas não avancem com os outros incentivos'. Foi este quadro que encontrei”, resume Arons de Carvalho.

Ora, o secretário de Estado decidiu que era tempo de alterar este estado de coisas e pugnar pela "moralização" do sector. E isso só se podia fazer alterando as regras do porte-pago.

O processo conheceu duas fases. Numa primeira, quando o Governo era minoritário, a proposta enviada à Assembleia da República não colheu a simpatia dos grupos parlamentares, que a viam como um entrave ao futuro da imprensa regional e local. Nessa altura, só o PCP se mostrou aberto a discutir, mas colocando uma premissa: os comunistas aceitavam a redução para $90 \%$ nos jornais quinzenários e mensários, mas não concordavam com nenhum corte nos diários e semanários. Arons de Carvalho faz da posição do PCP uma leitura eminentemente política: é que uma boa parte das publicações de periodicidade mensal e quinzenal estão ligadas à Igreja Católica. Os comunistas estavam assim convencidos que "matavam" muitas publicações conservadoras (um termo ligado ideologicamente à Direita), resguardando, ao mesmo tempo, os títulos que lhes estão mais “próximos” ${ }^{20}$. Arons não aceitou. A “moralização" ficou adiada.

Com a conquista, nas legislativas de 1999, de 115 deputados (no limiar da maioria absoluta), o PS passou a ter outras condições para fazer aprovar diplomas na Assembleia da República. Sabendo disso, Arons de Carvalho voltou à carga. Percorreu o país de lés-a-lés, falou com todas as associações do sector em busca de apoios, tentou sensibilizar outra vez alguns partidos da oposição (nesta segunda etapa já não abordou o PSD. Com o CDS/PP não chegou a conversar em nenhuma altura), escreveu a todos os directores dos órgãos de comunicação social regional e local, explicou as suas razões na imprensa nacional e nalguns media locais e regionais.

Apesar disso, a medida governamental provocou protestos vindos de praticamente todas as associações ligadas à imprensa regional e local (Associação Portuguesa de Imprensa, Associação de Imprensa Cristã, Associação de Imprensa Regional do Algarve, Associação Portuguesa de Imprensa Regional e União Portuguesa de Imprensa Regional) $)^{21}$.

Em sucessivos comunicados enviados para os filiados e em sucessivas reuniões onde se juntavam os associados, o argumento foi sempre o mesmo: o repúdio veemente do "sistema de aplicação e comparticipação" do porte-pago, por este pôr "em causa a sobrevivência de muitos jornais regionais, locais e para as Comunidades”. O sistema,

\footnotetext{
${ }^{20}$ A leitura de Arons de Carvalho faz sentido e é reveladora da opinião que os partidos políticos têm sobre a imprensa regional e local: braços culturais que servem a difusão das suas ideologias.

${ }^{21}$ A Associação de Imprensa Não Diária foi a única que concordou com a medida, tendo mesmo participado activamente na feitura do esqueleto do decreto-lei em causa.
} 
de acordo com os contestatários, "traduz-se num atentado ao direito constitucional a ser informado, uma vez que vai obrigar a aumentar o preço que o assinante está a pagar, o que, em muitos casos, se saldará por uma ruptura da assinatura, reduzindo assim as possibilidades e diversidade da informação disponível”.

Com a esmagadora maioria da imprensa regional local contra si, Arons não tinha outra hipótese senão procurar apoios no Parlamento. Foi o que fez. Mas também aí encontrou gigantes resistências. Da esquerda à direita, praticamente todos os partidos se opunham à medida. Todos, excepto o Bloco de Esquerda. Para "espanto" do secretário de Estado, os bloquistas concordaram com a redução no porte-pago e permitiram, com os seus votos, que a medida passasse no Parlamento.

O novo diploma entrou em vigor em Março de 2001. Aplicado a publicações cujo peso não ultrapasse os duzentos gramas, o Decreto-Lei 56/2001 determina que a expedição passa a ser comparticipada em $95 \%$ se o jornal for enviado para um assinante residente no estrangeiro. No que diz respeito à expedição para território nacional, passam a beneficiar de uma comparticipação de $80 \%$ nos custos os jornais que tenham cinco profissionais ao seu serviço (três deles jornalistas) e com tiragem média de cinco mil exemplares e com periodicidade igual ou inferior à trissemanal; os jornais com pelo menos três profissionais ao seu serviço, dois dos quais jornalistas, tiragem média de três mil exemplares e com periodicidade superior à trissemanal e igual ou inferior à semanal; os jornais com pelo menos dois profissionais, um deles jornalista, e uma tiragem média de mil exemplares; e os jornais com apenas um profissional ao seu serviço, uma tiragem média de mil exemplares e com periodicidade superior à semanal e igual ou inferior à quinzenal. Depois de uma fase de adaptação, em Janeiro de 2002 o Decreto-Lei passou a ser integralmente aplicado. Os valores de ajuda no porte-pago passaram a ser de $60 \%$ e $80 \%$, consoante as situações.

E por que razão foram reduzidos os apoios? Porque o Governo entendeu que as regras do jogo estavam falseadas, uma vez que muitos jornais regionais e locais, podendo utilizar gratuitamente e a eito os serviços dos CTT, enviavam milhares de exemplares para casa de pessoas que nem sequer eram assinantes do jornal. O que trazia óbvias vantagens: exibiam-se tiragens elevadas junto dos anunciantes e dos poderes locais, de modo a atrair mais publicidade, mesmo que nem um exemplar sequer da publicação fosse colocado à venda nas bancas.

Falta, contudo, a parte politicamente mais relevante desta história. É que Arons de Carvalho teve também que gerir e ultrapassar os temores dentro do próprio Governo, onde imensos colegas o alertaram para o sarilho em que se estava a meter e, sobretudo, para as consequências que daí podiam advir para o Executivo. De tal modo que, quando o diploma subiu a Conselho de Ministros, acabou por ser aprovado por um fio. Um fio que é, parece-nos, de uma enorme relevância para o que nos propusemos aqui discutir.

Os ministros, conta o secretário de Estado, temiam que o país profundo se erguesse contra o Governo, depois de posto em prática o corte no porte-pago. No meio da discussão, um deles avançou um argumento decisivo: se era certo que a aprovação da medida causaria danos ao Executivo, não era menos certo que esses danos seriam 
menores quanto menos fossem os jornais locais e regionais a levantar-se contra o Governo. Por isso, havia que avançar rapidamente com o corte e esperar que alguns jornais locais e regionais desaparecessem. Assim, a luta dos proprietários das publicações seria feita com uma tiragem limitada. Caso não se optasse por essa via, seria feita com uma tiragem ilimitada e, ainda por cima, sustentada pelo Governo.

Isto é: a decisão final do Governo foi tomada não porque o Executivo estivesse convencido da bondade da medida, ou de que ela beneficiaria, no futuro, a imprensa local e regional, mas porque o que interessava era minimizar os danos. Evitar o conflito.

\section{3. Novo Governo, novas regras}

O tempo encarregar-se-ia de provar duas coisas.

Primeira: meses volvidos sobre a redução do porte-pago, era já claro para Arons de Carvalho que, além da "moralização", a medida não tinha surtido o efeito desejado. “Os dados mais recentes dos CTT demonstram que o número de exemplares distribuídos baixou pouco, se os compararmos com os anteriores à entrada em vigor da lei. A quebra de tráfego postal de jornais regionais, de acordo com os dados dos CTT, limitou-se a cerca de $15 \%$ entre Janeiro e Fevereiro de 2001 e idênticos meses de 2002, o que revela que nem mesmo o fim do período transitório, que decorrera desde Março até ao fim do ano, provocou qualquer diminuição significativa no número de jornais ou mesmo na circulação" (Carvalho, 2002: 115, 116). Os dados de que dispõe o actual governante com a tutela do sector (Feliciano Barreiras Duarte, secretário de Estado-adjunto do ministro da Presidência) corroboram o facto. "Poucos títulos desapareceram e na circulação existem mesmo alguns números que mostram um aumento" 22 . Pode perguntar-se: a dura luta travada por Arons de Carvalho de nada valeu? Ou será que os números apenas provam que uma medida não faz uma política?

Segunda: apesar dos exíguos efeitos da "moralização" encetada no Governo socialista, estava "partida a pedra”, se nos é permitida a expressão, necessária para o lançamento de uma verdadeira reforma no sector. Curiosamente, é num Governo em que está o PSD que o seu desenho se acentua. E dizemos curiosamente porque não só o passado não mostra uma apetência especial deste partido para encarar os verdadeiros problemas da imprensa local e regional, como alguns dos seus dirigentes máximos se opuseram com veemência às alterações por que pugnou Arons de Carvalho. Houve mesmo quem garantisse que, regressado ao Governo, o PSD retomaria o porte-pago a $100 \% .^{23}$

Relevante é, desde logo, o facto de o programa do XV Governo Constitucional voltar a acentuar a defesa da imprensa regional pelo lado dos apoios. "O Governo quer assegurar que o recente processo de concentração de empresas coexista de forma harmoniosa com as iniciativas de pequena e média dimensão, regionais e locais. Isso

\footnotetext{
${ }^{22}$ Todas as declarações atribuídas a partir daqui a Feliciano Barreiras Duarte resultam de uma entrevista feita em 22 de Janeiro de 2003 no âmbito da recolha de materiais para a elaboração da tese de mestrado. O uso dessas declarações neste trabalho foi devidamente autorizado.

${ }^{23}$ Os pedidos de esclarecimento feitos, na altura, pelo grupo parlamentar do PSD ao Governo, cuja análise não cabe aqui, são bem ilustrativos deste facto.
} 
significa defender um regime de concorrência e definir um quadro de apoio a algumas actividades de maior risco, como é, por exemplo, o caso da imprensa regional". Sucede que este chapéu é apenas uma pequena parte do que o Governo de coligação PSD/CDS-PP promete fazer com a imprensa local e regional.

$\mathrm{Na}$ verdade, este modelo proteccionista não bate certo com o "modelo empresarial" que o Governo quer pôr em marcha no sector. E que fica mais claro quando se olha para o programa do XVI Governo Constitucional. "Será implementado um sistema de apoios que obedeça a aspectos de maior racionalidade, com melhor gestão por parte das empresas e do Estado, criando-se as condições para que a comunicação social regional e local se afirme como um forte instrumento de coesão nacional e de promoção do desenvolvimento do país à escala regional, distrital e local". Mas a "redução do peso do Estado na comunicação social regional e local será feita depois de um período de transição durante o qual os apoios serão mais diversificados e mais adequados às exigências do sector, designadamente na área da formação e da inserção de profissionais, visando o surgimento de grupos empresariais de âmbito regional de média dimensão, gerando condições para que os órgãos de comunicação se possam modernizar e fazer face a uma situação que, no futuro, terá mais mercado e menos Estado.”

“O modelo assente na carolice e no apoio do Estado está perto da falência”, entende Barreiras Duarte. Por isso, "há que escolher caminhos alternativos. Tínhamos dois possíveis: ou caminhávamos para o modelo liberal (o Estado saía do sector e o mercado fazia a selecção), ou ficaríamos no meio termo, optando pelo modelo empresarial. Optámos por este.”

E em que se traduz este modelo? "Na necessidade de melhorar a qualificação do sector, de aprofundar a empresarialização e de permitir que o Estado dê apoios premiando o mérito e aqueles que são profissionais. Os jornais e as rádios vão ter oportunidade de receber de forma maciça, num período transitório de três anos, novos apoios para que se criem as condições mínimas para que o sector se profissionalize”. Findo esse período, subentende-se, o mercado fará a selecção.

Um plano de formação para o sector (apostas na gestão empresarial, no marketing e publicidade, na maquetagem, em animadores de rádio, entre outras coisas), a criação de instrumentos de apoio à contratação de jornalistas profissionais, a elaboração de um plano nacional de promoção da leitura, uma majoração dos apoios para os media locais e regionais do interior do país estão entre as medidas que o Governo conta pôr em prática.

Estamos já bem longe do modelo proteccionista que o Governo propõe no seu programa. Na verdade, o modelo, embora híbrido, tem, no limite, uma forte componente liberal, na medida que o Estado propõe o seu afastamento da imprensa local e regional, ainda que não o faça de supetão. A melhor prova é a sua atitude em relação ao famigerado porte-pago. "Nunca o porte-pago voltará aos $100 \%$. Bem pelo contrário, ele irá diminuir paulatinamente", assegura o governante.

A definição concreta destas medidas foi antecedida por um périplo que Barreiras Duarte decidiu fazer por todo o País ${ }^{24}$, à semelhança do que realizara Arons de 
Carvalho. Das auscultações aos actores do sector, o governante tirou duas conclusões: as associações "não têm conseguido transmitir fielmente o pensamento" de quem faz e trabalha nos jornais e rádios; e "o sector tem consciência de que a actual situação, a não ser alterada, fará com que muitos jornais e rádios fechem, criando-se assim uma má imagem do mesmo".

Relevante para esta discussão é ainda o facto de Barreiras Duarte "ter sido avisado" por vários colegas do Governo da embrulhada em que se iria meter. "Achavam que eu devia ter procurado fazer o tradicional: reunir com as associações do sector e decidir de forma a não criar grandes problemas”. Não há melhor maneira de evitar o conflito.

As alterações desenhadas pelo actual Governo para a imprensa local e regional sofreram, entretanto, dois percalços. A entrada em funções de um novo Executivo, resultante da indigitação do anterior primeiro-ministro, Durão Barroso, para a liderança da Comissão Europeia ${ }^{25}$, fez com que alguns diplomas que se encontravam já para promulgação pelo Presidente da República, Jorge Sampaio, regressassem aos ministérios de origem para sofrerem alterações. No caso da reforma dos media regionais, o Governo garante que se trata apenas de questões de pormenor ${ }^{26}$.

Sucede que, entretanto, o Sindicato dos Jornalistas (SJ) veio a público protestar contra o facto de não ter sido ouvido pela tutela, facto que, por si só, tornaria os diplomas ilegais, na óptica do SJ. Nesse sentido, a estrutura sindical chegou mesmo a pedir a Jorge Sampaio que rejeitasse a proposta governamental. Mais: a intervenção do Provedor de Justiça, do movimento sindical e das estruturas sindicais partidárias do PSD e do CDS/ PP foi igualmente pedida pelo SJ. À data da conclusão deste ensaio, sabia-se apenas que o Governo mantivera já reuniões com o Sindicato para ultrapassar esta questão. ${ }^{27}$

O actual Executivo, liderado por Santana Lopes, fez, entretanto, saber que a reforma não sofrerá alterações de monta. A aprovação, no Conselho de Ministros de 7 de Outubro de 2004 de vários projectos de Decreto-Lei sobre o sector confirmam a inexistência de mudanças de fundo. ${ }^{28}$

A reforma divide-se, genericamente, em cinco diplomas ${ }^{29}$ (um deles dedicado à Lei da Rádio) e é complementada com cinco decisões administrativas. Vejamos, de forma sintética, as linhas mestras que interessam à imprensa local e regional.

\footnotetext{
${ }^{24}$ Barreiras Duarte garante que, entre os dias 14 de Fevereiro e 28 de Março de 2003, foram realizadas cinquenta reuniões em todos os distritos do País e regiões autónomas, com os responsáveis dos novecentos jornais e 354 rádios locais e regionais existentes em Portugal.

${ }^{25}$ À data da conclusão deste texto, Durão Barroso ainda não tinha sido formalmente eleito presidente daquele organismo da União Europeia.

26 "Governo faz alterações ao pacote legislativo sobre meios locais", in Público de 30/07/04.

27 "Imprensa regional - Sindicato dos Jornalista pede ao Presidente que rejeite diploma" - Despacho da Agência Lusa de 18/06/04. "Sindicato quer participar nas alterações legislativas dos media regionais" - Despacho da Agência Lusa de $05 / 08 / 04$.

${ }^{28} \mathrm{O}$ comunicado do Conselho de Ministros de 7 de Outubro de 2004 faz referência à aprovação dos seguintes projectos: Projecto de Decreto-Lei que estabelece o sistema de incentivos do Estado à Comunicação Social; Projecto de Decreto-Lei que estabelece as regras aplicáveis à distribuição das campanhas informativas e publicitárias do Estado pelas rádios locais e pela imprensa regional; Projecto de Decreto-Lei que altera pela décima vez o Código da Publicidade; e Projecto de DecretoLei que estabelece o regime de porte-pago para as publicações periódicas. Ver ainda "Imprensa Regional: Governo aprova diplomas". Despacho da Agência Lusa de 7/10/2004.
} 
i) Alteração do regime dos incentivos lançando uma única medida que visa:

- incentivo à criação de parcerias estratégicas;

- requalificação de infra-estruturas;

- gestão e valorização profissional;

- desenvolvimento tecnológico e multimédia;

- difusão do produto jornalístico;

- expansão cultural e jornalística nas comunidades portuguesas;

- introdução de um critério diferenciador entre regiões mais e menos desfavorecidas;

ii) Diploma do porte-pago

- é adoptado o princípio de que se trata de um apoio à leitura (assinantes) e não aos jornais, como acontecia até aqui;

- novo regime reduz a comparticipação média do Estado para 50\% dos custos de expedição, contra os actuais $80 \%$;

- após os três anos de transição previstos, as publicações que não tenham qualquer requisito de profissionalização perdem o porte-pago;

iii) Publicidade do Estado

- nas campanhas de valor superior a quinze mil euros, passa a ser obrigatório destinar $25 \%$ desse valor à comunicaçãoo social regional e local. Actualmente, o valor é de $15 \%$ para campanhas superiores a cem mil euros;

iv) Alteração ao Código da Publicidade

- os boletins pertencentes à administração local não podem ter publicidade, salvo se forem empresas municipais;

v) Decisões administrativas complementares

- apoio à contratação de profissionais. O Estado suporta parcialmente os salários durante três anos, sendo depois os jornalistas contratados em definitivo pelas empresas;

- plano de formação descentralizado para diversas áreas;

- plano e campanha para incentivar a leitura da imprensa;

- protocolo com a Agência Lusa em que o Estado subsidia o serviço orientado para as necessidades dos meios locais e regionais;

- criação de um portal ao serviço da comunicação social regional e local.

Com estas medidas, o Estado conta combater a pulverização do sector e espera que entre cinquenta e cem meios locais e regionais fiquem pelo caminho (não se sabe

\footnotetext{
${ }^{29}$ Os cinco diplomas seguiram para o Presidente da República. A partir da data de recepção, o Chefe de Estado tem
} sessenta dias para os promulgar (ou não), sendo depois publicados em Diário da República. 
se a curto, médio ou longo prazo, o que faz alguma diferença para avaliar o impacto pretendido com a reforma). Também por isso, os títulos criados nos cinco anos imediatamente a seguir à entrada em vigor da nova lei não terão direito a qualquer tipo de apoio do Estado.

\section{Conclusão}

Recordemos a hipótese de trabalho que decidimos lançar no início do ensaio: mais do que incentivar o desenvolvimento da imprensa local e regional, as políticas - ou a falta delas - definidas para este sector pelos vários Governos têm sido um factor de constrangimento à sua evolução.

A análise dos programas de Governo e das circunstâncias em que foram tomadas algumas das mais importantes decisões sobre a imprensa regional e local portuguesa permite concluir que, sobre este sector, sempre os Governos tiveram uma visão limitada, consubstanciada no facto de verem nos apoios a melhor - senão a única - forma de ajudar ao seu desenvolvimento. Trata-se, a nosso ver, de uma atitude errada, mas que não nos espanta, visto que, se nos ficarmos apenas pelo exercício do poder dos últimos detentores da tutela do sector, percebemos que raramente houve uma ideia clara - uma política, enfim - sobre o que fazer para criar no país condições para o desenvolvimento sério de jornais locais e regionais, equilibrando quantidade e qualidade.

A definição de uma política para o sector não se pode nunca resumir ao desenho, mais ou menos bem gizado, de um modelo de apoios do Estado. Não se trata de defender o fim das ajudas. Fazê-lo de supetão seria seguramente contraproducente. Trata-se, isso sim, de perceber que os desafios que se colocam aos jornais locais e regionais só podem ser ultrapassados estudando, um a um, os problemas que os afectam e definindo, a partir daí, uma política clara que os ajude a crescer em tamanho e importância.

É, obviamente, mais cómodo - e politicamente mais interessante - distribuir subsídios. Mas isso não faz, como temos vindo a notar, uma política. Mais: tende a prejudicar quem investe com seriedade em projectos jornalísticos, porque mantém artificialmente o que naturalmente o mercado rejeitaria.

Não nos parece abusivo concluir que o actual estado da imprensa regional e local portuguesa é tributário da ausência de uma política digna desse nome para o sector. E mesmo quando alguma decisão estratégica (para recorrer à tipologia clássica) se toma sobre ele (caso do porte-pago), percebemos, pela movimentação dos actores, que estamos a falar, para regressar a Lukes, de uma decisão que fica na fronteira entre a visão bidimensional e a visão tridimensional do poder. Porquê? Porque os vários Governos sabiam que a questão, trazida para a agenda pública, podia causar grande celeuma (visão bidimensional), como causou ${ }^{30}$. Mesmo assim, quando se tratou de tomar uma decisão tão importante, o que prevaleceu foi o argumento a favor da minimização do conflito (visão tridimensional).

\footnotetext{
${ }^{30}$ É, de resto, extremamente curioso reparar, pela leitura dos livros onde estão compiladas todas as intervenções feitas nos vários congressos da Associação de Imprensa Não Diária, como os donos dos jornais regionais e locais de dimensão
} 
Quando olhamos, por exemplo, para os nossos vizinhos espanhóis (Espanha tem apenas 213 jornais locais e regionais, contra os novecentos portugueses), percebemos bem a importância que os media regionais e locais ali têm. A evolução neste e noutros países fez-se com o apoio do Estado, mas nunca na dependência do Estado. O caso mais paradigmático é, porventura, o dos países nórdicos. Apesar dos excelentes índices de leitura, o Estado continua a apoiar os jornais. Sucede que esses apoios não são dados, as mais das vezes, para os títulos sobreviverem, mas sim para crescerem ${ }^{31}$.

Ora, em Portugal, acontece exactamente o contrário. Em bom rigor, o Estado é "dono" de uma boa parte dos novecentos títulos da imprensa local e regional, porque sem as suas ajudas eles muito provavelmente não sobreviveriam.

E é mau “dono”, acrescente-se. Tomemos apenas como exemplo o porte-pago, uma singularidade nacional, na medida em que, com excepção de França - onde a comparticipação do Estado é de apenas 30\% - não existe apoio idêntico em toda a Europa. Entre 1991 e 2003, foram gastos mais de 208 milhões de euros (ver Quadro I). Para fazer uma conta actual, trata-se de um valor quase quatro vezes superior ao que o Governo inscreveu no Orçamento de Estado de 2005 para apoios no âmbito da nova lei do arrendamento, divulgada no dia 24 de Setembro de 2004. A avaliação pode ser feita de outra forma. Só entre 1999 e 2003, o Estado despendeu mais de 89 milhões de euros em incentivos directos e indirectos (ver Quadros III a VII). As perguntas são legítimas: a qualidade e o número de leitores da imprensa local e regional subiram? A resposta é a esperada: não. Subiu o número de títulos $(40 \%)$, mas baixou o índice de leitura $(11 \%)$.

As mudanças previstas pelo actual Governo parecem, contudo, abrir uma porta por onde possa entrar ar fresco para imprensa local e regional. Ainda assim, os atrasos na apresentação definitiva da reforma reiteram a dificuldade em decidir. Da mesma forma, o aviso feito pelos colegas de Barreiras Duarte quanto aos “perigos” que as mudanças encerram traz de volta a tentativa de eliminar o conflito na tomada de decisões.

Era bom que assim não fosse, porque, como tentámos mostrar ao longo do trabalho, neste tempo em que a "crise de esperança" nos enreda "num quotidiano higienizado e atolado no indiferentismo e absentismo políticos" (Pinto et al., 2003: 9,10), a imprensa local e regional, além de tudo o mais, pode ser um instrumento decisivo para impedir que se enruguem ainda mais as nossas identidades pessoais e comunitárias e que se reganhe a importância da cidadania e da intervenção e participação na esfera pública.

Se, um dia, um candidato à presidência da República portuguesa decidir anunciar a sua disponibilidade na imprensa local e regional, estaremos seguramente mais perto desse desejável patamar.

razoável pedem o progressivo afastamento dos apoios do Estado e a crescente profissionalização das empresas, enquanto os donos dos pequenos jornais acentuam a visão "poética" da imprensa regional e local.

${ }^{31}$ Para um melhor entendimento dos apoios que os Estados europeus dão à sua imprensa, ver "Incentivos do Estado - Como a Europa apoia a Imprensa", texto de Ana Cristina Cruz disponível em www.aind.pt 


\section{Referências}

Alves, A. A. (1990) “Imprensa local e desenvolvimento”, in Cadernos do Noroeste, vol. 3, Braga: Universidade do Minho.

Alves, A. A. (1991) “A qualidade de vida na imprensa local. Imagens e valores em destaque”, in Cadernos do Noroeste, vol. 4, Braga: Universidade do Minho.

Alves, A. A. (1992) “A informação construída”, in Cadernos do Noroeste, vol. 5. Braga: Universidade do Minho.

Cádima, F. R. (1999) Desafios dos Novos Media, a Nova Ordem Politica e Comunicacional, Lisboa: Editorial Notícias.

Camões, P. (1997) "Processos de tomada de decisão numa organização municipal: estudo exploratório", Factos \& Ideias, II Série, Vol. 1, n. ${ }^{\circ} 1$, pp. 79-99.

Carvalho, A. A. (2002) Valerá a Pena Desmenti-los?, Coimbra: Minerva.

Comunicación Rexional en Europa, s/d., Xunta de Galicia.

Congressos da Associação de Imprensa Não Diária, volumes I a VI.

Correia, J. C. (1998) “Jornalismo Regional e Cidadania”, disponível em www.bocc. ubi.pt

Correia, J. C. (1998) “A região e o espaço público: um contributo crítico”, disponível em www.bocc. ubi.pt

Decreto-Lei n. ${ }^{\circ}$ 56/2001, de 19 de Fevereiro. Presidência do Conselho de Ministros.

Decreto-Lei n. ${ }^{\circ}$ 106/88, de 16 de Março - Estatuto da Imprensa Regional.

Dowding, K. M. (1991) Rational Choice and Political Power, England: Edward Elgar Publishing Company.

Esteves, J. P. (1990) “Comunicação regional e local em Portugal: a situação da imprensa e os grandes desafios do audiovisual”, in Cadernos do Noroeste, vol. 3. Braga: Universidade do Minho.

Esteves, J. P. (2003), Espaço Público e Democracia, Lisboa: Colibri.

Fortuna, C. (1999) “Os novos espaços públicos: identidades e espaços culturais”, Revista Crítica de Ciências Sociais, n. ${ }^{\circ}$ 54, pp. 139-155.

García, X. L. (1992) A Prensa Local e Comarcal en Galicia, Lugo: Edicións Léa.

García, X. L. et al. (1998) "El valor social de la información de proximidad”, Revista Latina de Comunicação Social, número 7, Julho de 1998, La Laguna (Tenerife).

URL: http://larazillo.com/latina/a/68xose.htm

García, X. L. (1999) "La información de proximidad en la sociedad global”, Revista Latina de Comunicação Social, número 13, Janeiro de 1999, La Laguna (Tenerife).

URL: http://larazillo.com/latina/a1999c/140xose.htm

García, X. L. (2000) "La comunicación del futuro se escribe con L de local”, Revista Latina de Comunicação Social, número 34, Outubro de 2000, La Laguna (Tenerife).

URL: http://www.ull. es/publicaciones/latina/aa2000kj1/w34oc/41xose.htm

Gravend, J. (1993) Le Journal municipal, Paris: Presse et Information.

Guéry, L. (1993) La Presse régionale et locale, Paris: Presse et Information.

"Imprensa Regional: sobrevivência, redenção ou a última oportunidade?”, s/d. Câmara Municipal de Oeiras.

"L'Europe de la presse quotidienne régionale" (1992), SPQR.

Lopes, J. T. (1999) "O estranho próximo de nós”, Revista Crítica de Ciências Sociais, n. ${ }^{\circ}$ 54, pp. 155-163

Lukes, S. (1974) Power: A Radical View, Londres: MacMilan Press.

Moreira, A. (1989) Ciência Política, Coimbra: Almedina.

Pinto, M. et al. (2000) A Comunicação e os Media em Portugal (1995-1999), cronologia e leituras de tendências, Braga: Edição do Departamento de Ciências da Comunicação da Universidade do Minho.

Pinto, M. et al. (2003) Televisão e Cidadania - Contributos para o debate sobre o serviço público, Braga: Edição do Departamento de Ciências da Comunicação da Universidade do Minho.

Programas dos Governos Constitucionais de Portugal: I a XVI, Apresentação e Debate, AR - Divisão de Edições, Lisboa. 
Robertson, R. (2000) Globalização, Teoria Social e Cultura Global, Petrópolis: Editora Vozes.

Santos, B. S. (2001) Globalização: Fatalidade ou utopia?, Porto: Edições Afrontamento.

Santos, J. V. T. (2000) “As novas questões sociais globais”, Revista Crítica de Ciências Sociais, n. ${ }^{\circ} 57 / 58$, pp. 13-22.

Silva, A. C. (1995) As Reformas da Década, Venda Nova: Bertrand Editora.

Sousa, H. (1994), "Portuguese media - new forms of concentration”, disponível em www.bocc. ubi.pt

Sousa, H. (1999), “The liberalisation of media and communication in Portugal”, disponível em www.bocc. ubi.pt

Sousa, H. (2001), "Políticas da comunicação em Portugal”, Comunicação Apresentada no I Congresso Ibérico de Comunicação, Málaga.

\begin{tabular}{|c|c|}
\hline Quad & \\
\hline POR & \\
\hline Ano & $\begin{array}{r}\text { Montante } \\
\text { (valores em euros) }\end{array}$ \\
\hline 1991 & 14167550 \\
\hline 1992 & 17498370 \\
\hline 1993 & 22369495 \\
\hline 1994 & 19689495 \\
\hline 1995 & 17467490 \\
\hline 1996 & 15395290 \\
\hline 1997 & 13848030 \\
\hline 1998 & 14581095 \\
\hline 1999 & 16615605 \\
\hline 2000 & 16193740 \\
\hline 2001 & 13866995 \\
\hline 2002 & 13660206 \\
\hline 2003 & 13209696 \\
\hline TOTA & 208563057 \\
\hline
\end{tabular}

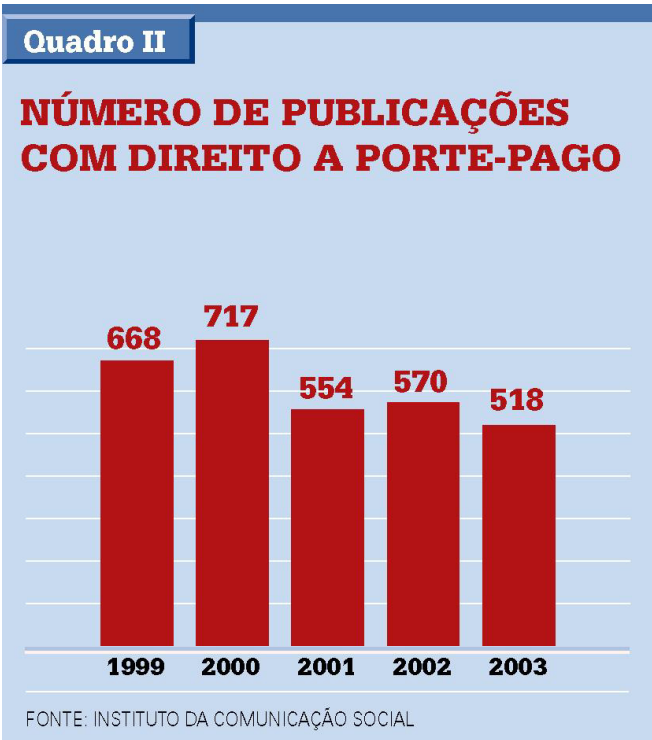




\section{Quadro III}

\section{MONTANTE TOTAL DOS INCENTIVOS (DIRECTOS E INDIRECTOS)}

Dados de 1999 (valores em euros)

TOTAL: 18765015

1573690

Incentivo à modernização tecnológica

9900

Incentivo à formacão e qualificação profissional 538820 Incentivos específicos 27000 Incentivo à edição de obras de comunicação social

\section{Porte pago} 16615605

\section{Quadro IV}

\section{MONTANTE TOTAL DOS} INCENTIVOS (DIRECTOS E INDIRECTOS)

Dados de 2000 (valores em euros)

TOTAL: 19777275

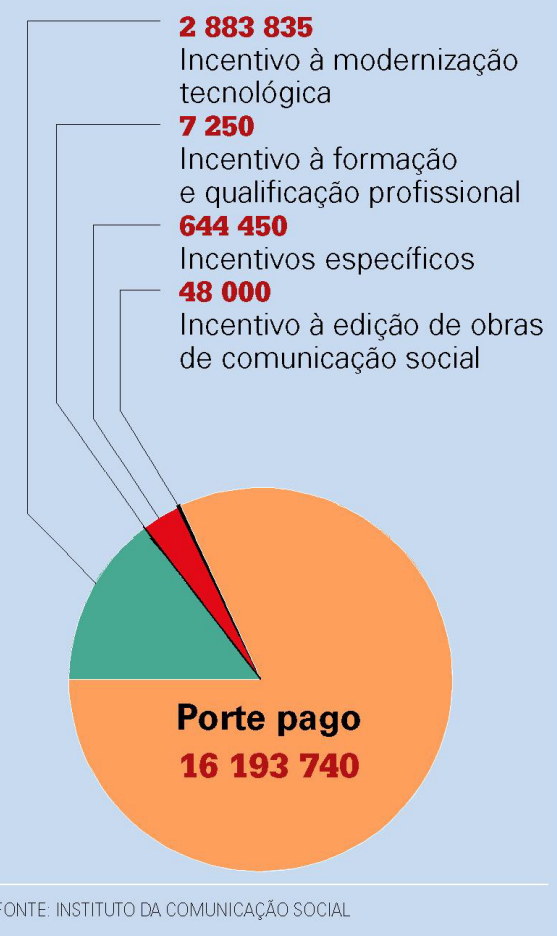



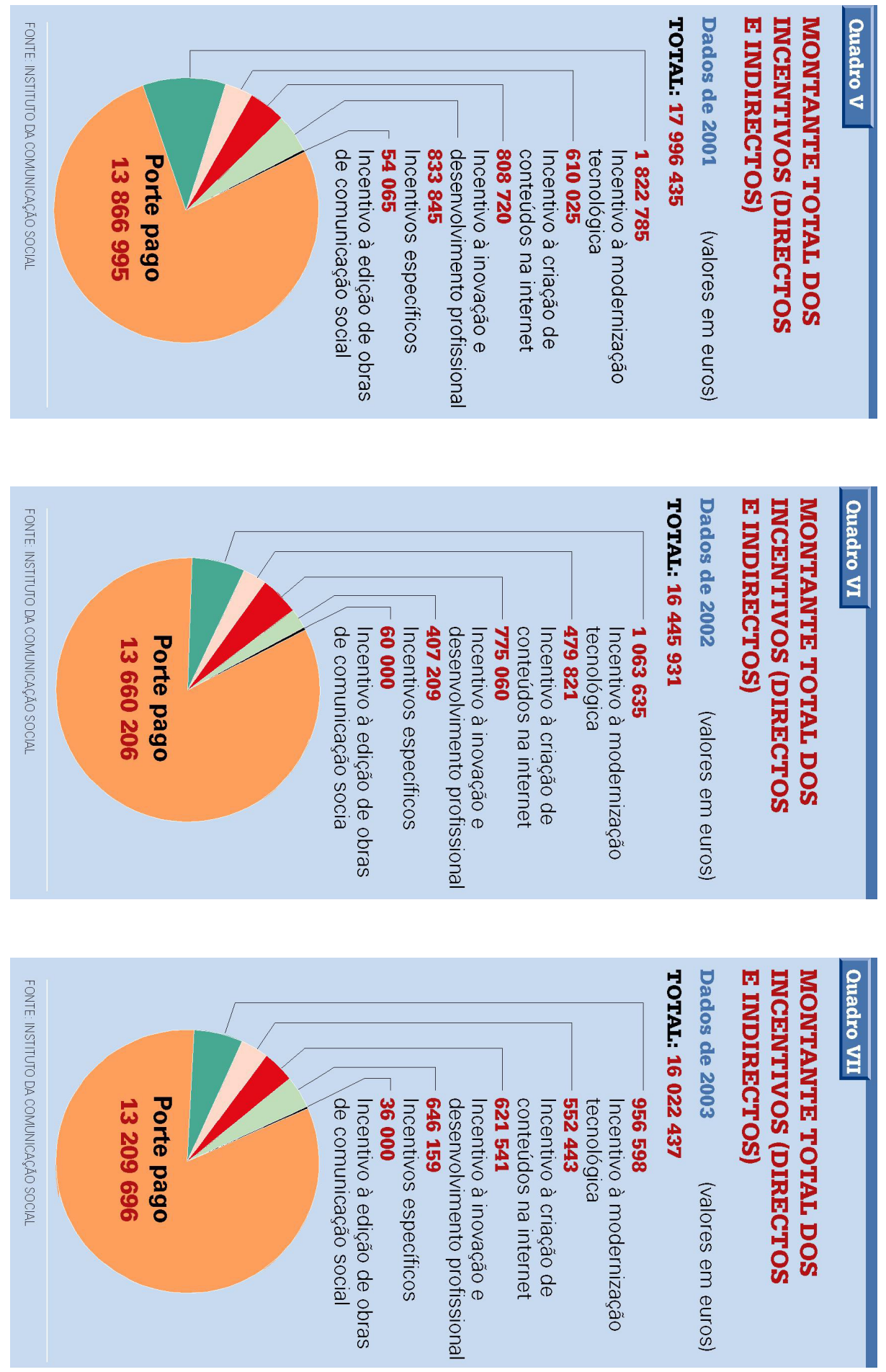